Прихожанов Валерій Олександрович здобувач кафедри господарського та трудового права МАУП, вул. Фрометівська, 2, м. Київ, 03039, тел.: (044) 490-95-00, e-mail: olyaprih@gmail.com, https://orcid.org/00000001-9659-6141

\title{
КОМПЕТЕНТНОСТНИЙ ПІДХІД ДО ВИЗНАЧЕННЯ СУТНОСТІ ЮРИДИЧНОЇ ВІДПОВІДАЛЬНОСТІ (на прикладі сфери промислової власності)
}

Анотація. В юриспруденції юридична відповідальність розглядається як один з основних елементів правового забезпечення охорони і захисту прав фізичних та юридичних осіб. У сфері господарсько-правової захисту охоронюваних прав суб'єктів господарювання - це ті (негативні) наслідки, що настають за порушення господарського законодавства.

До компетентностей суб’єктів господарювання (а отже i до їх відповідальності) входять повноваження, функції не тільки з ініціювання притягнення винної особи до відповідальності, застосування санкцій, а й інші компетентності. У сфері промислової власності - це створення умов, за яких би потенційні порушники не змогли б порушували встановлений правопорядок захисту цієї власності. Це також (для підприємств, які використовують власні інтелектуальні продукти) створення власної служби безпеки, яка б займалась захистом інновацій, нововведень, працювала над упередженням порушень прав інтелектуальної власності). До юридичної відповідальності господарюючих суб'єктів відносяться усі інші функції, обов'язки цих суб'єктів 3 досягнення своїх статутних цілей, вирішення завдань, що стоять перед ними.

Доцільно розрізняти юридичну відповідальність суб'єктів господарювання у вузькому (обов'язок застосування до винної особи примусових заходів за вчинене правопорушення) і широкому сенсі.

Юридична відповідальність у широкому сенсі, у більшості випадків, важливіша, ніж застосування санкцій. Обов'язки юридичної відповідальності у широкому сенсі можна інтерпретувати як компетентності відповідних осіб (посадових осіб, рядових працівників підприємства). Формування компетентностей посадових осіб і інших працівників підприємства зараз розглядається i в контексті вдосконалення їх освітньої підготовки. Ефективність цієї підготовки, а отже і розвиток компетентностей залежить, в свою чергу, від якості освіти і науки в країні. Саме з підвищенням їх якості 
пов’язані розроблені нами положення, що відносяться до підвищення рівня компетентностей суб'єктів господарювання (юридичної відповідальності суб’єктів господарювання у широкому сенсі).

Ключові слова. Юридична відповідальність, юридична відповідальність у широкому i вузькому сенсі, сфера охорони i захисту прав, порушення господарського законодавства, наслідки, що настають за порушення господарського законодавства, застосування санкцій.

Prykhozhanov Valerii Oleksandrovych Applicant of the Department of Economic and Labor Law MAUP, Frometivska St., 2, Kyiv, 03039, tel.: (044) 490-95-00, e-mail: olyaprih@gmail.com, https://orcid.org/0000-0001-9659-6141

\title{
COMPETENCE APPROACH TO DEFINING THE ESSENCE OF LEGAL LIABILITY (on the example of the sphere of industrial property)
}

\begin{abstract}
In jurisprudence, legal liability is considered as one of the main elements of legal protection and protection of the rights of individuals and legal entities. In the field of economic and legal protection of protected rights of economic entities - these are the (negative) consequences that occur for violations of economic legislation. The competencies of business entities (and hence their responsibility) include powers, functions not only to initiate the prosecution of the guilty person, the application of sanctions, but also other competencies. In the field of industrial property, it is the creation of conditions under which potential violators would not be able to violate the established legal order for the protection of this property. It is also (for companies that use their own intellectual products) the creation of its own security service, which would protect innovations, innovations, work to prevent infringements of intellectual property rights). The legal responsibility of economic entities includes all other functions, responsibilities of these entities to achieve their statutory goals, to solve the tasks facing them. It is advisable to distinguish between the legal liability of business entities in the narrow (the obligation to apply coercive measures to the guilty person for the offense) and in a broad sense. Legal liability in the broadest sense is, in most cases, more important than the application of sanctions. Duties of legal responsibility in a broad sense can be interpreted as the competence of the relevant persons (officials, ordinary employees of the enterprise). The formation of competencies of officials and other employees of the enterprise is now considered in the context of improving their educational training. The effectiveness of this training, and hence the development of competencies, depends, in turn, on the quality of education and science in the country. It is with the improvement of their quality that we have developed the provisions relating to the increase of the level of competencies of economic entities (legal responsibility of economic entities in a
\end{abstract}


broad sense).

Keywords. Legal liability, legal liability in a broad and narrow sense, the sphere of protection and defense of rights, violations of economic legislation, the consequences of violations of economic legislation, the application of sanctions.

Постановка проблеми. В юриспруденції юридична відповідальність розглядається як один з основних елементів правового забезпечення охорони і захисту прав фізичних та юридичних осіб. У сфері господарсько-правової захисту охоронюваних прав суб'єктів господарювання - це ті (негативні) наслідки, що настають за порушення господарського законодавства. Наприклад, відповідальність суб'єктів господарювання за порушення антимонопольноконкурентного законодавства (Глава 28 ГКУ).

Під юридичною відповідальністю суб'єктів господарювання звично розуміють обов'язок застосування до правопорушника примусових заходів. Тобто, це застосування заходів примусу до осіб, які вчинили правопорушення. Обов'язковими іiі (юридичної відповідальності) ознаками $\epsilon$ вина особи і наявність правопорушення.

Застосування заходів примусу до осіб, які вчинили правопорушення, $\epsilon$ обов'язком суб'єктів господарювання.

Розповсюдженою в літературі точкою зору є трактування юридичної відповідальності як реалізації санкції, як міри державного примусу, що базується на юридичному i громадському осуді правопорушника, i встановленні для нього певних негативних наслідків у формі обмежень особистого, майнового або організаційного характеру [1; с.54-55]. В цьому сенсі притягнення до відповідальності є одним 3 повноважень, однією 3 компетентностей особи, чиї права порушені. У нашому випадку, це суб'єкти господарювання.

В той же час до компетентностей суб’єктів господарювання (а отже і до їх відповідальності) входять повноваження, функції не тільки з ініціювання притягнення винної особи до відповідалтьностіі, застосування санкцій, а й інші компетентності. Наприклад, у сфері промислової власності - це створення умов, за яких би потенційні порушники не змогли б порушували встановлений правопорядок захисту цієї власності. Це, зокрема, кваліфіковане використання патентного захисту, передбаченого чинним законодавством, в т.ч. одержання деклараційного патенту. Це також (для підприємств, які використовують власні інтелектуальні продукти) створення власної служби безпеки, яка б займалась захистом інновацій, нововведень, працювала над упередженням порушень прав інтелектуальної власності). I, безумовно, до юридичної відповідальності господарюючих суб'єктів відносяться усі інші функції, обов'язки цих суб'єктів з досягнення своїх статутних цілей, вирішення завдань, що стоять перед ними.

Отже, будемо розрізняти юридичну відповідальність суб'єктів господарювання у вузькому (обов'язок застосування до винної особи примусових заходів за вчинене правопорушення) і широкому сенсі.

Виходячи 3 вищенаведеного, можна стверджувати, що юридична відповідальність у широкому сенсі, у більшості випадків, важливіша, ніж 
застосування санкцій. До речі, якщо суб'єкт господарювання буде належним чином виконувати усі свої обов'язки (в тому числі і 3 попередження правопорушень), то можливо, санкції і не знадобилось би застосовувати. Окрім тих, звичайно, які виникають 3 деліктів.

Обов'язки юридичної відповідальності у широкому сенсі будемо інтерпретувати як компетентності відповідних осіб (посадових осіб, рядових працівників підприємства).

Стосовно розрізнення юридичної відповідальності суб’єктів господарювання у вузькому і широкому сенсах - то тут ми не претендуємо на оригінальність. Важливо, на нашу думку, по перше, спробувати вирішити проблеми забезпечення набуття суб'єктів господарювання своїх компетентностей $\mathrm{i}$, по друге, зробити це стосовно саме сфери промислової власності.

Аналіз останніх досліджень та публікацій. Питанням юридичної відповідальності суб'єктів господарювання у вузькому сенсі приділяється достатньо уваги (роботи відомих юристів, починаючи від О.Е. Лейста, Г. Ф. Шершеневича $\mathrm{i}$ до сучасних праць Є. А. Агеєвої, A.I. Денисова, С. Г. Стеценка, Н. М. Хуторян та ін. ). В той же час, враховуючи нові виклики в сфері здійснення права промислової власності (патентний тролінг тощо), розгляд питань юридичної відповідальності суб'єктів господарювання є актуальним. Не менш актуальною є розробка положень, що відносяться до юридичної відповідальності суб'єктів господарювання у широкому сенсі.

Мета статті. Основними цілями дослідження, результати якого викладаються в цій статті, були:

1. Проаналізувати ефективність діючої юридичної відповідальності суб'єктів господарювання у вузькому сенсі стосовно сфери промислової власності;

2. Розробити положення, що відносяться до підвищення рівня компетентностей суб'єктів господарювання, тобто, до юридичної відповідальності суб’єктів господарювання у широкому сенсі.

Виклад основного матеріалу. Такі результати інтелектуальної творчої діяльності як винаходи, корисні моделі i промислові зразки (складові промислової власності) - посідають значне місце серед об'єктів інтелектуальної власності. Разом 3 товарними знаками, знаками обслуговування, найменуваннями місць походження товарів вони охоплюються загальною назвою «Об'єкти промислової власності». Це встановлюється ст. 1 Паризької конвенції про охорону промислової власності від 20 березня 1883 р., що поширює свою дію і на територію України. Слід вказати на те, що згідно з Паризькою конвенцією, промислова власність розуміється «у найбільш широкому значенні і розповсюджується не тільки на промисловість і торгівлю у власному значенні слова, але також i на галузі сільськогосподарського виробництва і добувної промисловості, та на всі продукти промислового або природного походження». 
Єдиного права промислової власності як юридичного інституту, покликаного опосередкувати економічні відносини промислової власності, у чинному законодавстві не існує. Право промислової власності в об’єктивному сенсі представлено низкою відокремлених інститутів, коло яких утворюють: інститут патентного законодавства, інститут законодавства про засоби індивідуалізації, інститут законодавства про недобросовісну конкуренцію.

Під засобами індивідуалізації товарів та учасників господарського обігу (скорочено «засоби індивідуалізації») розуміється група об'єктів інтелектуальної власності, зокрема: знаки для товарів та послуг або торговельні марки, зазначення походження товару, комерційні найменування та промислові зразки, що використовуються для того, щоб відрізнити один товар або учасника господарського обігу від іншого.

Засоби індивідуалізації $\epsilon$ матеріальним вираженням таких нематеріальних активів підприємства як гудвіл, ділова репутація та лояльність споживачів. Засоби індивідуалізації $\epsilon$ ключовим активом у портфелях інтелектуальної власності підприємств, діяльність яких заснована на активній маркетинговій стратегії.

Щодо аналізу ефективності діючої юридичної відповідальності суб’ єктів господарювання у вузькому сенсі у сфери промислової власності.

Проведемо такий аналіз на прикладі законодавства про недобросовісну конкуренцію. Як зазначалось у літературі, переважна кількість актів недобросовісної конкуренції пов'язана 3 порушенням прав об'єктів інтелектуальної власності, таких як: винаходи, корисні моделі, торгові марки, промислові зразки та інше. Конкурентна боротьба в інтелектуальній сфері не завжди йде законними напрямками. Мають місце «скупка мізків», промислове шпигунство, "піратська продукція" [3].

Протягом декількох останніх років були введені заходи щодо захисту інтелектуальної продукції від недобросовісної конкуренції, які відповідали західним стандартам. Але вони не дали бажаних результатів через високий рівень недобросовісної конкуренції на ринку об'єктів інтелектуальної власності, широке розповсюдження піратської продукції, неліцензійних товарів, відсутністю традицій у вирішенні подібних проблем. Хоча слід відзначити, що проблеми недобросовісної конкуренції в інтелектуальній сфері обговорюються дуже активно, але відома лише незначна кількість оздоровчих ініціатив. За оцінками спеціалістів, у відомчих органах Укрпатенту розглядався лише 1\% випадків, кваліфікованих як «ultimo ratio» (піратство) [3]. Сьогодні до 95\% програмного забезпечення для персональних комп'ютерів в Україні — контрафактні. Для порівняння: такий же рівень неліцензійного використання програмного забезпечення, за даними агенції В5А, у В'єтнамі складає 99\%, у Китаї - 96\%, в Омані - 95\%, у середньому по пострадянським країнам - 95\%. Щодо країн 3 розвиненою ринковою економікою, де існують тривалі традиції боротьби з піратською продукцією, то найнижчий рівень піратства у США - 28\% [3]. Згідно зі звітами АМКУ загальна кількість припинених порушень у сфері недобросовісної 
конкуренції щорічно складає приблизно 12\% від загальної кількості припинених порушень у сфері захисту економічної конкуренції. Найбільш поширеними з них були поширення інформації, що вводить в оману (90\%). Решту склали неправомірне використання чужих позначень, рекламних матеріалів, упаковки - 4\%; досягнення неправомірних переваг у конкуренції шляхом порушення іншогозаконодавства - 5\%; введення у господарський обіг під своїм позначенням товару іншого виробника, порівняльна реклама, дискредитація суб'єкта господарювання, схиляння до бойкоту суб'єкта господарювання - $1 \%$ [2].

Великі проблеми в цій сфері виникають 3 приводу існування піратської (неліцензійної) продукції та особливостей перебігу цих процесів на ринку об'єктів інтелектуальної власності [3]. Значною проблемою є так званий «патентний тролінг».

Судовий експерт Науково-дослідного центру судової експертизи 3 питань інтелектуальної власності Юрій Охромєєв у своїй статті «Патентний тролінг - ахіллесова п'ята системи охорони інтелектуальної власності в Україні» пише про те, що держава має забезпечувати реальну відповідальність недобросовісних заявників - патентних тролів та відшкодовувати збиток особам, які його зазнали внаслідок таких дій або за рахунок патентного троля, або з державного бюджету [4].

Автор пропонує створення ефективного механізму настання реальної відповідальності за вчинення дій, що мають ознаки недобросовісної конкуренції із використанням прав на об’єкти інтелектуальної власності [4].

В рамках такого механізму настання реальної відповідальності добре спрацював би введений в українське кримінальне законодавство інститут кримінальної відповідальності юридичних осіб.

Відносно юридичної відповідальності суб'єктів господарювання у широкому сенсі. Як зазначалось - це виконання суб'єктами господарювання усіх своїх обов'язків. Нагадаємо, що обов'язки юридичної відповідальності у широкому сенсі будемо інтерпретувати як компетентності відповідних осіб (посадових осіб, рядових працівників підприємства). Це відповідає вимогам інноваційного розвитку, які з врахуванням загальносвітових тенденцій, на нинішньому етапі є особливому актуальними.

Формування компетентностей посадових осіб i iнших працівників підприємства зараз розглядається і в контексті вдосконалення їх освітньої підготовки. Ефективність цієї підготовки, а отже і розвиток компетентностей залежить, в свою чергу, від якості освіти i науки в країні. Саме 3 підвищенням їх якості пов’язані розроблені нами положення, що відносяться до підвищення рівня компетентностей суб'єктів господарювання (юридичної відповідальності суб'єктів господарювання у широкому сенсі).

Висновки. Доцільно розрізняти юридичну відповідальність суб'єктів господарювання у вузькому i широкому сенсах. У вузькому сенсі - це застосування санкцій, а у широкому - виконання суб'єктами господарювання усіх інших своїх обов'язків.

Обов’язки юридичної відповідальності у широкому сенсі будемо 
інтерпретувати як компетентності відповідних осіб (посадових осіб, рядових працівників підприємства). Це відповідає вимогам інноваційного розвитку, які 3 врахуванням загальносвітових тенденцій, на нинішньому етапі $\epsilon$ особливо актуальними.

\section{Jimepamypa:}

1. Тищенко Г.В. Екологічне право : навчальний посібник для студентів юридич-них вузів та факультетів. - к.: юмана,2001.-256 с.

2. Швець Г.О. Недобросовісна конкуренція в сфері інтелектуальної власності //

3. Хрустальова В. Проблеми становлення цивілізованого конкурентного середовища на інтелектуально-інформаційному ринку України. [Електронний ресурс]. - Режим доступу: http://www.bezpeka.com/ru/lib/spec/law/competitive-environment-information-market. html

4. Охромєєв Ю. Патентний тролінг - ахіллесова п'ята системи охорони інтелектуальної власності в Україні //Юридична газета. - 2 лютого 2015.

\section{References:} Ukrainian].

1. Tishhenko, G.V. (2001). Ekologichne pravo [Environmental law]. Kyiv: jumana [in

2. Shvec', G. O. (2016). Nedobrosovisna konkurencija v sferi intelektual'noï vlasnosti [Unfair competition in the sphere of intellectual property ]. Visnik Priazovs'kogo derzhavnogo tehnichnogo universitetu. Serija : Ekonomichni nauki - Visnyk of Pryazovsky State Technical University. Series: Economic Sciences, 31(1), 267-271 [in Ukrainian].

3. Hrustal'ova, V. Problemi stanovlennja civilizovanogo konkurentnogo seredovishha na intelektual'no-informacijnomu rinku Ukraïni [Problems of formation of a civilized competitive environment in the intellectual and information market of Ukraine]. (n.d.). Retrieved from http://www.bezpeka.com/ru/lib/spec/law/competitive-environment-information-market.html [in Ukrainian].

4. Ohromeev, Ju. (2015). Patentnij troling - ahillesova p'jata sistemi ohoroni intelektual'noï vlasnosti v Ukraïni [Patent trolling - Achilles heel of the intellectual property protection system in Ukraine].Yuridichna Gazeta - Juridichna gazeta. [in Ukrainian]. 